\title{
Institute of Excepted Perils under the Rotterdam Rules 2009
}

\section{Nikola Mandić}

The Rotterdam Rules set forth, on the lines of the HagueVisby Rules, a number of excepted perils when the carrier will not be liable for the damage to cargo. The institute of excepted perils was established by the Hague Rules almost 90 years ago, and is still implemented in practice. For such cases exceptionally the carrier is not liable under the principle of assumed guilty, but under the principle of proven guilty. In the preliminary activities for concluding the new international convention, the possibility has been considered of abolition of the institute of excepted perils has been considered, but in the end nevertheless, on the initiative of mainly maritime states, it has been retained, developed and more contemporarily styled, i.e. concerted with the requirements of the contemporary maritime transport. The Rotterdam Rules in Article 17, Paragraph 3, taxatively cite the excepted perils due to which the carrier will be able to exculpate from liability. The key difference is that error in navigation is no longer an excepted peril. Especially important novelties introduced by the Rotterdam Rules are exemption of the carrier from liability due to the acts of piracy, terrorist attacks, undertaking measures to avoid or prevent possible damage to the environment, and alike.

\section{KEY WORDS}

$\sim$ Rotterdam Rules

$\sim$ Liability of the carrier

$\sim$ Excepted perils

$\sim$ Error in navigation

University of Split, Faculty of Maritime Studies, Split, Croatia

e-mail:nmandic@pfst.hr

\section{INTRODUCTION}

Carrier's liability is one of the crucial problems regarding the contract of carriage of goods by sea. The carrier is liable to the other contracting party for damage incurred by violation of contractual liability. The main obligation of the carrier is to carry the goods to the place of destination and deliver them to the consignee. Therefore, the carrier is liable for damages to goods he has taken in for carriage and for the delay in delivery. Carrier's liability in the carriage of goods by sea at the international level is regulated by a number of international conventions. However, none of the adopted international conventions has been universally accepted.

The first internationally agreed convention was the International Convention for the Unification of Certain Rules of Law Relating to Bills of Lading dating back to as early as 1924, also known as the Hague Rules. The Rules have been almost universally adopted, and undoubtedly represent a successful international instrument that is still standing. The main reason for laying down the Hague Rules was to limit the freedom of contracting to protect the user of carriage services, as such freedom by the economically stronger party, the carrier, was used against them. The Hague Rules in Article 4, Paragraph 2, provide for special cases due to which the carrier will not be liable for loss or damage resulting from them. Those cases are referred to as excepted perils, and they represent an exception from the general liability principle.

Although the Hague Rules were satisfactorily accepted, in the course of their implementation certain shortcomings were noticed and requirements for their updating appeared. The Hague Rules were revised by enacting two Protocols on revising the International convention for the Unification of Certain Rules of Law Relating to Bills of Lading in 1968, well-known by the name of Visby Rules, that together with the text of the Hague Rules represent the Hague-Visby Rules, in 1979 referred to as SDR Protocol. The main reason for undertaking amendments was a lack of uniformity of judicial practice in the implementation of the Hague Rules, progress of cargo handling and transport 
technology, especially containerization, reduction in value of the world's currencies by inflation, and by introduction into maritime contract law of special drawing rights, as determined by the International Monetary Fund, instead of gold franc. By the Hague-Visby Rules or SDR Protocol did not affect the institute of excepted cases laid down by the Hague Rules.

The other international convention regulating the carriage of goods by sea is United Nations Convention on the carriage of goods by sea concluded in 1978, referred to as the Hamburg Rules. The main reason for concluding the new convention was protection of the user of carriage services, and these are the states mainly importing and/or exporting cargo without a strong fleet. An essential characteristic of the Hamburg Rules is that they significantly stiffen the carrier's liability. The Hamburg Rules provide some interesting up-to-date solutions, but have not gained wider acceptance. The Hamburg Rules have a different approach to solving problems of carrier's liability and do not provide for the institute of excepted perils.

The third international convention regulating the carriage of goods by sea is the United Nations Convention on Contracts of the International Carriage of Goods Wholly or Partly by Sea concluded in 2009, referred to as the Rotterdam Rules. Laying down the Rotterdam Rules was undertaken due to the fact that nowadays in the world to regulate the relations in the carriage of goods by sea more than one system of international convention legal regulations are simultaneously implemented, which certainly does not contribute to the standardization of maritime transport law. A specific feature of the Rotterdam Rules with regard to the other international conventions is that besides the carriage of goods by sea they also regulate the multimodal transport. Although the Rotterdam Rules contain a number of new solutions, in certain cases there has been an attempt to include also the traditional solutions from the Hague-Visby Rules and Hamburg Rules. Thus, they retained the implementation of the institute of excepted cases in accordance with the Hague-Visby rules. However, the Rotterdam Rules have not been implemented and it is very hard to say if it is ever going to happen.

\section{THE BASIS OF CARRIER'S LIABILITY}

Article 17 of the Rotterdam Rules provides for the basis of carrier's liability for the loss, damage or delay. According to Paragraph 1 of the Article, the carrier is liable for loss or damage to goods, as well as for delay in delivery, provided the claimant can prove that the loss, damage or delay, or an event or circumstances having caused or contributed to the damage, occurred in the course of carrier's liability, as set forth in Chapter 4 regulating carrier's liability. It follows that the carrier's liability is assumed if the shipper can prove that the carrier has taken the goods in for carriage in apparent good order and condition, and that the goods have been damaged in the course of the carriage.
According to Paragraph 2 of the Article, the carrier is not liable wholly or partly in accordance with Paragraph 1, if he proves that the cause or one of the causes of loss, damage or delay cannot be attributed to his fault or fault of the persons mentioned in the Article 18, for which the carrier is responsible, on the basis of the Convention, in case of breach of obligation caused by acts or omissions committed by those persons. ${ }^{1}$ So, the carrier is exculpated from liability or part of it, if he proves that the cause or one of the causes of damage cannot be attributed to his fault or fault of the persons for whom he is responsible.

According to the Rotterdam Rules the carrier is not liable on the basis of assumed guilty. The burden of proof is distributed so that the claimant proves that the loss, damage or delay occurred in the course of the period of carrier's liability, he does not have to prove what the cause of the damage is, but only that the damage occurred. When the claimant proves that the damage occurred, the burden of proving is transferred to the carrier, and the carrier, to exculpate himself from liability or part of liability, has to prove that the cause or one of the causes of loss, damage or delay cannot be attributed to his fault or fault of any other person under his liability.

The same legal basis of carrier's liability is also set forth in the Hague-Visby Rules and Hamburg Rules, which means that it has not changed since the conclusion of the first international convention. With the Rotterdam Rules the basis of carrier's liability has been differently styled and stipulated by nomotechnical combination of wordings from the Hague-Visby Rules and Hamburg Rules. The authors of the Rotterdam Rules have closely studied potential changes and taken care that the new styling and content does not significantly derogate from the Hague-Visby Rules, and that will mainly preserve valuable interpretations of certain key provisions originated from court and business practice by the implementation of the Hague-Visby Rules.

\section{CARRIER'S LIABILITY FOR EXCEPTED PERILS}

Excepted perils represent specific events or circumstances providing for the carrier's non-liability, i.e. exceptions from general principles of carrier's liability. The institute of excepted perils consists of specific risks to which cargo is exposed during carriage, and which by their intensity exceed the intensity considered normal during carriage. By the Institute of excepted perils a number of cases have been provided for when the carrier will not be liable for damage incurred to goods. For excepted

1. According to Article 18 of the Rotterdam Rules the carrier is liable for acts and omissions of: the performing party, master or ship's crew members, employees of the carrier or agent, or any other person who performs or undertakes to perform any one of the carrier's responsibilities on the basis of contract of carriage, to the degree to which that person acts, either directly or indirectly, upon carrier's requirement or under his supervision. 
perils the carrier is responsible according to the principle of proven guilty, and not, as in other cases, according to the principle of assumed guilty, which is definitely more favourable for the carrier.

The burden of proving is so distributed that the carrier has to, in order to exculpate himself from liability or part of liability, prove the existence of one of taxatively listed excepted perils, i.e. how one or more of the specified excepted circumstances caused or contributed to the loss, damage or delay, as well as proximate cause between that case and the damage. However, the carrier is not then finally exculpated from liability but proving of his guilt is permitted. The user of carriage services can prove that the circumstances specified are not the cause of the damage incurred, but others, that can be attributed to carrier's fault and for which consequently the carrier is liable. These other circumstances that can be attributed to the carrier's fault are ship's unseaworthiness, ship's improper crewing, equipping and supplying, as well as the fact that the ship's holds or her other parts in which goods are carried are not ready and safe for taking in, carriage and protection of goods. In case the carrier does not manage to prove that he has fulfilled the obligations imposed on him, it is considered that there is proximate cause between his omission of due diligence and the damage incurred, so he will be liable. If the damage has occurred due to the existence of one of the excepted perils, but the damage is also consequence of carrier's omission to exert due diligence in making the ship seaworthy, in that case the carrier is liable for the whole damage. The carrier will be liable if his fault, or fault of the persons for whose acts and omissions he is responsible, is proved.

In the Rotterdam Rules the Institute of excepted perils has been retained on the lines of, mutatis mutandis, formulation of excepted perils from the Hague-Visby Rules. In Article 17, Paragraph 3, of the Rotterdam Rules excepted perils are set forth, i.e. the releasing circumstances on the basis of which the carrier can, in case he proves that one or more of the excepted perils contributed wholly or partly to the damage incurred, exculpate from his liability. As a difference from the Hague-Visby Rules, with the Rotterdam Rules the excepted perils also cover the damages due to delay, which is acceptable as some listed perils can also cause the consequence of delay in the delivery of goods. The excepted perils in the Rotterdam Rules have been altered, finalized and more contemporarily styled which is due to a global approach that the Rotterdam Rules have in the regulation of the whole subject. The greatest asset for the inclusion of the Institute of excepted perils into the Rotterdam Rules is that so far they have been widely implemented internationally and as much as possible rely on laid-down sound judicial practice.

Article 17, Paragraph 3, of the Rotterdam Rules prescribes how the carrier is exculpated wholly or partly from his liability in compliance with the Paragraph 1 of the Article if, except by proving not guilty as prescribed in the Paragraph 2 of the
Article, he proves that one or more of the following events or circumstances have caused or contributed to the loss, damage or delay: (a) act of God; (b) perils, dangers and accidents of the sea or other navigable waters; (c) war, hostilities, armed conflicts, piracy, terrorism, riots, civil commotions; (d) quarantine restrictions, interferences or impediments created by governments, public authorities, rulers or people, including detention, arrest or seizure, or judicial prosecution to which the carrier or any other person mentioned in the Article 18 have not contributed; (e) strikes, lockouts, stoppages or restraints from labour; (f) fire on the ship; ( $g$ ) latent defects non-discoverable by due diligence; (h) act or omission by the shipper, documentary shipper, supervising party, or any person for whose acts the carrier is liable according to the Article 33 or $34^{2}$; (i) loading, handling, stowing or unloading of the goods according to the agreement in compliance with the Article 13, Paragraph $2^{3}$ except if the carrier or performing party has performed such act on behalf of the shipper, documentary shipper or consignee; $(j)$ wastage in bulk or weight or any other loss or damage arising from a latent defect, quality or inherent vice of the goods; (k) Insufficiency or defective condition of packing or marking not performed by the carrier or on behalf of carrier; (l) saving or attempting to save life at sea; $(\mathrm{m})$ Reasonable measures to save or attempt to save property at sea; (n) reasonable measures to avoid or attempt to avoid damage to the environment; (o) acts of the carrier in pursuance of the powers he has in line with Articles 15 and $16^{4}$.

\subsection{Act of God}

Act of God is an external event that could not have been foreseen, avoided or removed. Act of God at sea commonly occurs as heavy weather, while the common actions of wind and seas are not considered act of God. Heavy weather has characteristics of act of God only if it is an unpredictable occurrence of exceptional force that cannot be overcome by implementation of standard seamanship and wisdom. Exceptionally heavy weather that could have been forecast and avoided (by following meteorological reports) also does not have the characteristics of act of God. In judicial practice so far there has not been a reliable criterion that could help, with the application of the Beaufort scale, to judge

2. Article 33 of the Rotterdam Rules regulates the shipper's responsibility for other persons, whereas Article 34 of the Rotterdam Rules regulates issuance of sea-carriage documents or electronic transport records.

3. Article 13 of the Rotterdam Rules special obligations, among which in Article 2 it provides for the possibility for the carrier and shipper to agree that loading, handling, stowing or unloading of the goods can be performed by the shipper, documentary shipper or consignee providing such a contract has to be specified in the contract clauses.

4. Article 15 of the Rotterdam Rules contains provisions on goods that can become dangerous, while Article 16 of the Rotterdam Rules regulates sacrificing goods in the course of a sea voyage. 
directed against the determined system of government in an organized way. Such actions are possible even in conditions of civil war, but the term does not imply civil commotions. The possibility of hostility being started by an individual is excluded.

An armed conflict is a conflict of armed forces in which arms have been used, i.e. armed force. Modern conventions of war (humanitarian) law instead of the term war contain the term armed conflict. By an armed conflict is not considered a border incident in the state of peace, of little significance, in which insignificant forces take part. According to the literature available, the concepts of armed conflict and war are used synonymously, therefore it is considered that there is no difference between the conceptual determination of war and armed conflict in the sense of the Rotterdam Rules.

The concept of piracy is used as a criminal case in international law or as piracy representing offence of a certain state's rules. If piracy has been performed in the territorial sea of a state, there is no piracy as international crime, but it is considered piracy according to the internal law of that state, and it can be prosecuted and punished by the coastal state only. Piracy has to be motivated by private ends or any other personal incentive, and not by any means, explicitly, by a political intent. In this very fact lies the main difference between piracy and maritime terrorism, which is primarily motivated by political intents. Article 101 of the United Nations Convention on the Law of the Sea prescribes that piracy consists of the following acts: 1 . Any illegal acts of violence or detention, or any act of depredation committed for private ends by the crew or the passengers of a private ship or a private aircraft and directed: a) on the high seas, against another ship or aircraft or against persons or property on board such ship or aircraft; b) against a ship, aircraft, persons or property in a place outside the jurisdiction of any state; 2 . Any act of voluntary participation in the operation of a ship or of an aircraft, with knowledge of facts making it a pirate ship or aircraft; 3. Any act of inciting or of intentionally facilitating an act described in Paragraph 1 or 2 . The Hague-Visby Rules do not cite exclusively the term piracy but those acts are implied by the term acts of a public enemy. As a difference from the Hague-Visby Rules, in the Rotterdam Rules piracy is explicitly cited as an excepted peril. It is logical since piracy at sea is a contemporary peril. Recently, there has been a dramatic rise in the number of acts of piracy, therefore it is important to undoubtedly stipulate such an event as an excepted peril.

Terrorism is a threat to international safety that does not know borders and that afflicts states and population, independent of geographical or any other factors. Terrorism is said to represent a form of political fight that is conducted by violence and instilling fear. The definition by the United Nations Security Council from 2004 determines terrorism as any act performed to the goal of causing death or inflicting serious injuries to civilians in order to instil fear among population, or compel a government or international organizations to refrain from acting. Terrorism can generally be defined as use of illegal violence, or threat by violence to civil population (with no prior determination) so as to reach political, religious, ideological or other goals. Political murders, destroyed property, destructive attack of civil and military targets such as sabotage, often represent acts of terrorism. Violence that is undertaken with no political goals is not considered terrorist attack, although it instils fear. By terrorism is also intended the threat of use of force with the intent of producing political effects by provoking a state of terror in a group of persons. Acts of terrorism are not directed to targets of immediate attack, but to the social order and its values. Motivation for a terrorist act is often deeply ideological, and individuals or groups of persons believe the criminal and unacceptable act to be a just way of reaching mostly political goals, wherein democratic order and democratic values are imperilled, as well as civil liberties and, above all, right of innocent people to life.

Maritime terrorism is a more recent security threat that has seen its expansion in the past decade. Taking into consideration the volume of the world's merchant trade and vulnerability of maritime transport, it is clear that maritime terrorism causes substantial material losses. This imperils economic and financial, and indirectly also national and international security. By mastering modern technologies terrorists present threats by causing as large a number of human life losses as possible, largescale ecological disasters and disfunctionality of the system of world maritime transport.

Riot implies an organized and overt uprise, armed revolt against the authorities with the intent to substitute them for new ones. It follows that there is riot when the participants' action is directed towards the government, i.e. the system of government. Consequently, the basic aim of the riot is political, overthrow of the existing authorities. These have to be movements of masses on a limited area for which it is enough to be spontaneous and sporadic.

It is the case of commotions in general when in a common action with instances of violence a significant number of persons participate with a common intent. Commotion implies resistance to authorities by returning force, a movement of a mass. The concept of civil commotions does not have a legal definition. Civil commotions, as a specific type of human behaviour, are positioned between revolt ${ }^{6}$ and civil war ${ }^{7}$. Civil commotions imply organized acting of persons whose intent is to create chaos, and it can arise in a spontaneous or organized way. Therefore, it is

6. Revolt implies disorders in which a number of persons take part whose behaviour at a public or private place is ungovernable and vehement.

7. Civil war implies armed conflicts within the borders of a state that are not considered international war, if those conflicts acquire certain political significance and distribution wider than limited riots. Accordingly, civil war from the aspect of international law is not a war. 
not necessary to prove the existence of a foreign organization that has inspired chaos. A cause of such an occurrence can be the differences in the political programme or goals, differences in ethnic, racial or religious viewpoint. Commotions differ from riots by their purpose, since the basic intent of the participants is not to dethrone authority, but their acting expresses dissatisfaction for other reasons (ethnic, racial, religious).

\subsection{Quarantine restrictions, interferences or} impediments created by governments, public authorities, rulers, or people including detention, arrest or seizure not attributable to the carrier or any other person for which the carrier is liable

Quarantine restriction implies hospital isolation (quarantine) to which the ship and persons coming from the areas caught by the phenomenon of dangerous epidemic diseases are submitted, or symptoms of one of the diseases have appeared among persons on board, or there are other reasons to suspect infection.

The conventional expression of impediment or obstacle caused by the government, public authorities or people comprises impediments or obstacles i.e. any violent interference into voyage or maritime venture undertaken by factual authorities in a foreign country, irrespective of whether the authorities are in relations of formal hostility with the state to which the ship belongs. This primarily refers to acts issued by any government or its organs, irrespective of the form of the acts or the form of government. It is irrelevant whether the relative act is legal, and the issuing subject does not have to be internationally acknowledged. It is considered that this exculpation peril includes embargo ${ }^{8}$, requisition of ship ${ }^{9}$ or cargo by declaration of bootie captured in war or at sea, and prohibition of import or export of cargo.

The conventional concept of detention, arrest or impediment, or prosecution by lawsuit is not easily defined. When it comes to lawsuits, it is considered that it has to be an extraordinary peril that the carrier could not have foreseen. However, the fact itself that the detention or arrest of the ship happened, even if it was due to the carrier's acting, does not deny the carrier his right to adduce that excepted peril. Otherwise, if the carrier was enabled to prevent such a situation by an act, and he omits to do so, then it is considered that he has no right to adduce those circumstances as an excepted peril.

8. Embargo is a general or partial prohibition of import or export, i.e. restriction of free commerce.

9. Requisition is the risk of seizure of ship by military or other authorities on the basis of powers of the state or compulsory seizure of the ship with charge.

\subsection{Strikes, lockouts, stoppages or restraints of labour}

The term strike in its general meaning can be defined as organized suspension from work so as to satisfy the requirements laid down to the employer. Most often strike is organized to get an increase in salary, improve work conditions and alike. However, strike can also be a result of compensation for dissatisfaction due to protests against something, or providing support, or expressing benevolence towards other workers in such acts. It follows that the nature of strike is not important as it can be economical, political or union. Strike often occurs as a kind of impediment to enforcement of contract on carriage, set up by cessation of work by workers' decision, so that in charter parties special clauses regulate the relations of parties in case of strike. Herein, it is not decisive whether the strike takes place on board ship or not. The carrier will be liable to the user of carriage services for damages caused by strike if he or his persons are guilty of strike occurrence and when they did not exert due diligence to prevent harmful consequences of the strike if it was possible.

Restraint of labour generally denotes suspension of work by the employer, it is a measure of employer's pressure on workers with whom he is usually in dispute, and the concept is also known as employer's strike. Essentially, restraints of labour as employer's countermeasure to the right to strike recognized to workers (i.e. trade unions) consists of the procedure of closing down enterprise due to labour dispute, of employer's refusal to make work assets available to workers and to pay them, in systematic employer's prohibition for a substantial number of workers to have access to their workplace with intent to reach certain goals. In carrying out a contract of carriage the measure of restraint of labour is attributed the same meaning as strike is. The carrier will be liable if he is guilty of mass restraint of labour, which is easier for the user of carriage services to prove than strike. However, the fact that the carrier as employer fired workers of his own free will does not always mean that he is personally guilty. Namely, commonly the carrier does not decide on his own whether he will lay off workers, since the decision is reached by his firm, and he has to comply with it, if he is not to subdue himself to hard material and moral sanctions.

Lockout has the same meaning as strike. By prevention to work are considered all the facts that generally or partly disable joint work operations and, thereby, ordinary carrying out carriage, and they do not have the character of strike or restraint of labour. Such impediments include economic reasons resulting from the contrary interests of employers and employees.

\subsection{Fire on the ship}

Fire is a chemical process due to combustion of substance and has a wider meaning than fire, because for the concept of fire on the ship it is not necessary that in the course of combustion 
flame occurs, but smoke is sufficient. It is a feature of the concept of fire that it develops chaotically, namely, that it spreads beyond the place determined for fire. The cause of fire is not relevant, as it is essential that the initial cause is fire. Damages to cargo due to fire have to develop on the ship. It is not important what caused fire and where it developed, on the ship or outside (on shore, in port, and alike). Damage due to fire is not only the one incurred by combustion of cargo, i.e. direct contact with fire, but it also includes every further causal damage incurred directly by fire (e.g. harmful smoke emissions), also including all harmful consequences of its extinguishing (damages due to water, chemical fire-fighting substances, etc.). In case that the fire developed or could not be prevented or localized due to lack of required fire-fighting apparatus on board, the carrier will be liable for the consequences of fire as he omitted the basic nonderogable obligation to make the ship seaworthy.

According to the Hague-Visby Rules the carrier has the right to exculpation from liability in case of fire on the ship even if it developed by fault of his assistants or servants. It is not important whether the fire developed due to a commercial omission or due to carrying out a technical-navigational function. Such a provision of the Hague-Visby Rules undoubtedly favours the carrier, as he is liable for the damage incurred to the cargo by fire on the ship only if it is proved that he set fire by a personal act or omission.

Fire on the ship is one of few excepted perils from the Hague-Visby Rules, which has been retained in the structure of the Hamburg Rules. In the Hamburg Rules the approach has been modified of the Hague-Visby Rules to liability of the carrier for the case of fire on the ship, but they, however, do not represent a new, significant approach. It can rather be characterized as a compromise solution. Instead of the general principle of presumed guilty, in the Hamburg Rules, for a case of fire on the ship the carrier is liable according to the principle of proven guilty, which has improved his position in proving the legal basis of liability for the case of damage due to fire on the ship. ${ }^{10}$ The Hamburg Rules exempt the carrier from this kind of liability if he can prove that the guilt for the fire cannot be attributed either to him, or to his servants. It follows that according to the Hamburg Rules the carrier is liable for the damage in case of fire both for the acts and for omissions of his servants, which is considered a good solution.

The Rotterdam Rules regulate the carrier's liability for fire on the lines of the Hamburg Rules. This has stiffened carrier's liability with regard to the Hague-Visby Rules. Although at preliminary meetings a possibility has been considered of cancelling fire on the ship from the excepted perils, due to its high importance for a number of delegations it was given up. According to the Rotterdam Rules the carrier has to prove the existence of fire

10. Article 5, Paragraph 4, of the Hamburg Rules regulates carrier's liability for damages caused by fire. and that the fire caused loss, damage or delay. It is important to emphasize that the Rotterdam Rules restrict the implementation of fire as an excepted peril only to the maritime part of the voyage and in cases when the fire developed on board. The ship has to be the one on board which the goods were either actually loaded or on which they were intended for carriage. This means, in fact, that the fire on a third unrelated craft cannot give the carrier the privilege of referring to the fire as an excepted peril. According to the Rotterdam Rules the carrier is liable for the fire on the ship caused by his servants. It follows that the intention of the composer of the Rotterdam Rules was stiffening of liability for fire as the carrier is also liable for the acts of his workers. Such a solution by the Rotterdam Rules is considered most acceptable and represents progress with regard to the conventional solution of the Hague-Visby Rules.

\subsection{Latent defects not discoverable by due diligence}

A latent defect of a ship is a defect or shortcoming in design, engines or equipment of the ship, which could not have been discovered by a professional using a reasonable degree of skill during regular inspection. The ship's defect is one of the features following from the features of materials themselves, but they differ from the features of natural characteristics of goods. A deficient state of the ship cannot be discovered by application of a common method. It becomes visible in the course of time, most often only after the damage has been incurred. The ship's defects, if not visible, represent an unprovided-for fact, uncertain circumstance, i.e. they cause unpredictable damage, so that the carrier can exculpate himself from such damage. It is, therefore, important to find out whether the defect on the ship is visible or is it a latent defect. A latent defect can cause loss or damage to the ship.

Ship's latent defect is related to the carrier's responsibility for the ship's conditions, i.e. his obligation to provide the user of carriage services with a seaworthy ship, because damage to the cargo can occur due to ship's unseaworthiness as a consequence of the ship's latent defect. To exculpate himself from liability, the carrier has to prove the fact of having exerted due diligence in making the ship seaworthy. It follows that the carrier is not liable for ship's latent defects. If, on the contrary, the defect is not latent, the carrier will be liable for the damage to the goods that results from such a defect, because by exerting due diligence he should have discovered it.

3.8 Act or omission of the shipper, the documentary shipper, the controlling party or any person for whose acts the shipper or the documentary shipper is liable

This excepted peril falls into the group of events or circumstances that remains outside the range of the carrier's 
in bulk or weight and damage or loss that occurs due to a special quality of goods, without the action of an extraordinary external cause. The natural quality of cargo is the normal quality of goods, due to which the goods become subject to regular risks to which it is exposed during carriage. Namely, the damage occurs to goods also in the normal, regular course of the voyage exactly as the result of natural qualities of goods, not in dependence of a transport accident or other risk. This natural wastage refers to the wastage which is no greater than the normal transport ullage that is prescribed in transport, i.e. it is determined according to common norms of wastage in the carriage of a certain type of cargo. In order to prove natural wastage, it is sufficient for the carrier to prove that the wastage ranges within natural ullage, without submitting proof of any other fact.

\subsection{Insufficiency or defective condition of packing or marking not performed by the carrier or on behalf of carrier}

The goods carried have to be packed so that in normal circumstances they are preserved from complete or partial loss or damage, and that they do not represent a risk to the environment. Errors in packing goods can be reflected in insufficient or defective packing. The concept of insufficient or defective packing implies such a manner of packing that does not comply with the prescribed or common standards for the carriage of each type of goods in a particular branch of transport. When goods are insufficiently or defectively packed, liability of the carrier is mitigated since the goods in such packing are more easily subject to deterioration, and it is harder for the carrier to undertake measures for their preservation. If damage to goods occurs despite normal proceeding of carriage, and if it results from insufficient or defective packing, the carrier is not liable for such damage.

Insufficient or defective marking of goods can result in mixing goods, mistaken delivery, loss or damage to goods. Then, as a rule, the carrier is not considered liable. For their identification, correct handling or stowing the goods carried are marked by special marks. The marks and numbers on goods have to be clearly drawn and engraved or inscribed so as to enable fast identification of cargo, and to warn of requirement of handling with care. Most often packages or pieces are marked with markings and numbers, fire stamps are impressed, inscribed, hammered, or cardboard, plastic or metal plates are made fast to packages, they are marked by different colours, and alike.

For carrier's liability with this excepted peril, it is important whether the carrier entered into sea-carriage document the remark of inexistent or defective packing. If a clean transport document has been issued, with the remark that the cargo has been received in apparently good state and conditions, the carrier will hardly be able to refer to insufficient or defective packing.

\subsection{Saving or attempting to save life at sea}

By the concept of saving, the activity directed to preservation and protection of the ship, goods and persons on board from the peril that represents a threat related to sea voyage, which can result in the loss of life or goods, is generally understood. The concept of saving also implies rendering assistance. The Rotterdam Rules do not contain the definition of saving of life at sea for the application of this exculpatory reason.

Saving of life at sea is compulsory. The user of carriage services, due to undertaking the act of saving, can suffer damage. The damage can occur due to the loss or damage to cargo, or indirectly, due to deviation from route. If the carrier proves that the damage to goods has occurred due to the act of saving or attempt at saving human life at sea, he will exculpate himself from liability. With regard to saving human life at sea, no attempt at saving can as such be attributed to the guilt of the ship's master, irrespective of any risk at which saving has been attempted or carried out, except if dolus or culpa lata can be objected to him.

Although the Hamburg Rules do not know the Institute of excepted perils, according to Article 5, Paragraph 6, the carrier is not liable for damage occurring due to measures undertaken for saving of human life at sea.

\subsection{Reasonable measures to save or attempt to save property at sea}

With saving property at sea, it is mainly spontaneous or contractual salvage as well as compulsory, in case of collision of ships. From the term itself of the excepted peril, it follows that the carrier will be able to refer to exculpation from liability due to saving of property only in case of undertaken reasonable measures. This undoubtedly includes compulsory saving of property (that due to ships' collision), whereas for all the other situations it is necessary to take into consideration the circumstances of the relative case.

The carrier will exculpate from liability to the cargo party only in case he has undertaken reasonable measures to carry out saving or attempt at saving property at sea, i.e. in the cases in which for the vessel being saved there is a factual, immediate threatening risk, and saving has to be within the limits of essential saving.

The Hamburg Rules, in Article 5, Paragraph 6, prescribe that the carrier is exculpated from liability for damages resulting from saving property only if it is reasonable.

\subsection{Reasonable measures to avoid or attempt to avoid damage to the environment}

At present, there is a great peril from the pollution of human environment by harmful substances. In the contemporary process 
of maritime transport a special emphasis is put on undertaking measures to protect marine environment. Marine environment pollution is determined by man's direct or indirect bringing into marine environment of substances or energy that have or can have disastrous results such as damage to living resources and marine life, threat to human health, disturbance to maritime activities, reduction in useful qualities of seawater and decreased attraction of coastal and sea environment. The negative effects to marine environment that can result from marine pollution can have far-reaching consequences for the entire environment. Therefore, the solution of the Rotterdam Rules is logical that, due to having undertaken reasonable measures to avoid or attempt to avoid damage to the environment, the carrier can use the privilege of exemption from liability.

Reasonable measures undertaken to avoid or attempt to avoid damage to the environment is a new excepted peril that is prescribed in the Rotterdam Rules. With this excepted peril it is important that the acts undertaken by the carrier have been reasonably undertaken, which is assessed from case to case.

\subsection{Acts of the carrier in pursuance of the powers he has of goods that may become a danger and sacrifice of goods during the voyage by sea}

The Rotterdam Rules prescribe as an excepted peril acting of the carrier with regard to the powers he has according to Articles 15 and 16. Article 15 of the Rotterdam Rules, that regulates goods that may become a danger, prescribes that the carrier can refuse to take in or load goods, and can undertake other measures that are reasonable, including unloading, destroying or rendering goods not dangerous, if the goods are, or it reasonably looks probable that during carrier's liability they will become a danger for persons, property or environment. Article 16 of the Rotterdam Rules, which regulates sacrificing goods in the course of sea voyage, prescribes that the carrier can sacrifice goods into the sea when this sacrifice is reasonably performed for general safety or to eliminate peril to human life or other property in common enterprise. Therefore, the Rotterdam Rules prescribe a new excepted peril to which the carrier can refer in case he acts according to the powers he has with regard to dangerous goods and sacrificing goods in the course of sea voyage. Such a solution is good and logical as the carrier in performing the above mentioned acts can cause damage to other cargo and, consequently, the privilege of referring to exculpation from liability that ensures him this excepted peril is justified.

\section{ERROR IN NAVIGATION- EXCEPTED PERIL THAT BECOMES HISTORY}

On comparing provisions prescribing excepted perils in the Hague-Visby Rules and Rotterdam Rules, it is visible that from the Rotterdam Rules a provision from the Hague-Visby Rules has been omitted, under which the carrier is exculpated from liability for loss or damage to cargo that has occurred or can be attributed to an act, undue diligence or omission of the master, crewmembers, pilot or another person in the carrier's service in the course of the voyage and conducting the ship. According to this excepted peril the carrier is liable only if there is his personal guilt. Exculpation of the carrier from liability due to error in navigation is also one of the most contested provisions of the Hague-Visby Rules. Such a form of exculpation from liability is not prescribed in any other branch of transport. ${ }^{11}$ Error in navigation as a cause of exculpation of the carrier from liability is a traditional peculiarity of the carriage of goods by sea, which has been intensively discussed for a number of years. The position of the carrier with regard to possibilities of exculpation from liability has been significantly modified by the Hamburg Rules, and this viewpoint has also been adopted in the Rotterdam Rules.

The Rotterdam Rules abandon error in navigation as a possible cause of exculpation of the carrier from liability for damage to goods he has taken in for carriage, which is, undoubtedly, one of the most significant modifications with regard to the Hague-Visby Rules. Although in the process of laying down the Rotterdam Rules the request has repeatedly been discussed of retaining the principle of exculpation the carrier from liability for error in navigation, finally the opinion prevailed of the opponents to the right of the carrier to exculpation. Such a provision of the Rotterdam Rules represents a norm that means stiffening of the carrier's liability. According to the Rotterdam Rules, the carrier is liable also for navigational activities of his servants.

This is considered a good solution of the Rotterdam Rules. In the past, in favour of the introduction of the provision on non-liability of the carrier due to error in navigation, the nature of the carriage of goods by sea and specific navigational risks were emphasized to which the carrier, as undertaker of navigational enterprise, is subject. Although this circumstance had significant influence to the introduction of exculpation due to error in navigation, at present it is hardly acceptable as justification for retaining that institute. In the past, the ship was entirely conceded to the persons acting on behalf of the carrier, of whose acts the carrier, who was most often physically distant from the ship and the crew, did not have any control, i.e. his influence on decision-making related to the ship's navigation was absolutely impossible. Today, however, navigational risk has been greatly decreased. Due to the development of engineering and technology, especially highly developed telecommunication

11. Exculpation for error in navigation was also implemented until 1955 in air transport, when it was abolished by the Hague Protocol to Amend the Convention for the Unification of Certain Rules Relating to International Carriage by Air from 1929. 
devices, and advanced nautical equipment, risks, if compared to some past times, can be more easily predicted and avoided. In any instant the carrier can be involved in all ship's navigational activities, and the persons working for him can easily contact him. It is, therefore, considered that in the contemporary conditions of carriage of goods by sea the carrier is in equal position as the ship's master and other members with regard to both their navigational and commercial activities.

\section{CONCLUSIONS}

Excepted perils are exceptions from the general principles of the carrier's liability. By the institute of excepted perils a whole range of cases when the carrier will not be liable for damage to goods is prescribed. For the excepted perils the carrier is liable under the principle of proven guilty, and not assumed guilty as in other cases, which for him is certainly more favourable.

The Rotterdam Rules, besides the already traditional excepted cases from the Hague-Visby Rules, have prescribed some new excepted perils. These are, primarily, acts of piracy, terrorism, loading, handling, stowing or unloading goods that according to the agreement are carried out by the cargo party, and not by the carrier, reasonable measures undertaken to avoid or attempt to avoid damage to the environment, as well as acting of the carrier relative to the powers he has with regard to dangerous goods and sacrificing goods in the course of sea voyage. An important novelty is introduced by the Rotterdam Rules related to the fire on the ship as an excepted peril. In this respect the Rotterdam Rules have stiffened liability with regard to the Hague-Visby Rules. In case of fire on the ship, carrier is liable also for the fire caused by his servants, which formerly was not the case. Such a solution of the Rotterdam Rules is considered more acceptable and represents progress with regard to the conventional solution of the Hague-Visby Rules.

The most important progress in the institute of excepted perils according to the Rotterdam Rules with regard to the HagueVisby Rules has been made by non-inclusion of error in navigation to the list of excepted perils. In this respect the Rotterdam Rules have adopted the solution of the Hamburg Rules, i.e. contemporary conditions governing navigation at sea. Namely, engineering and technology have recently made significant advances, and the conditions in navigation cannot be compared to those existing 90 years ago. The carrier, undoubtedly, can influence all navigational activities of the ship and participate in making all key decisions related to navigation in every instant. Therefore, it is considered justified that from such cases he no longer benefits. However, non-inclusion of error in navigation into the Rotterdam Rules can be one of the main reasons that they may never enter into force, or even if they do, they will not be generally applied. Namely, this is what a number of maritime states emphasize as the major impediment in abandoning the
Hague-Visby Rules and adopting the Rotterdam Rules. This is also favoured by the fact that the Rotterdam Rules in a more than four-year-long period have been ratified by only two states of the required minimum number of twenty.

\section{REFERENCES}

Amižić Jelovčić, P., (2012), Mjere suzbijanja pirata u Adenskom zaljevu, Rab: Zbornik radova In memoriam Prof. dr. sc. Vjekoslav Šmid, July 1, pp. 133 - 169.

Baatz, Y., Debattista, C., Lorenzon, F., Serdy, A., Staniland, H. and Tsimplis, M., (2009), The Rotterdam Rules: A Practical Annotation, London: Informa.

Bolanča, D., (1996), Odgovornost brodara za izuzete slučajeve, Split: Pravni fakultet Sveučilišta u Splitu.

Grabovac, I., (2011), Je li bilo kakvih promjena glede temelja odgovornosti prijevoznika u međunarodnim konvencijama o prijevozu stvari morem?, Split: Zbornik radova Pravnog fakulteta Sveučilišta u Splitu, 48(1), pp. 1-10.

Grabovac, I., (2010), Odgovornost prijevoznika u prijevozu stvari u Pomorskom zakoniku Republike Hrvatske i u međunarodnim konvencijama, Split: Književni krug.

Grabovac, I., (2011), Piratstvo - suvremena prijetnja sigurnosti plovidbe i događaj koji utječe na odgovornost pomorskog prijevoznika u prijevozu stvari, Split: Zbornik radova Pravnog fakulteta u Splitu, 48(3), pp. 461 - 474.

Grabovac, I. and Petrinović, R., (2006), Pomorsko pravo - pomorsko javno, upravno i radno pravo, Split: Pomorski fakultet Sveučilišta u Splitu.

Jakaša, B., (1983), Udžbenik plovidbenog prava, Zagreb: Narodne novine.

Miljanović, V., (2013), Savremeni pomorski terorizam, Beograd: Bezbednost, 55(1), pp. $109-121$.

Oršulić, l., (2008), (Ne)odgovornost pomorskog prijevoznika za štete na teretu uslijed nautičke pogreške, Zagreb: Poredbeno pomorsko pravo, 47(162), pp. 135 - 150.

Pavić, D., (2006), Pomorsko imovinsko pravo, Split: Književni krug.

Pedić, Ž., (2013), Odnos međunarodnoga i europskoga pravnog okvira za suzbijanje terorizma, Zagreb: Zagrebačka pravna revija, 1(1), pp. 57 - 80.

Radović, Z., (2003), Rizik terorizma u transportnom osiguranju, Zagreb: Poredbeno pomorsko pravo, 42(157), pp. 149 - 158.

Rudolf, D., (2012), Enciklopedijski rječnik međunarodnoga prava mora, Zagreb: Matica Hrvatska.

Skorupan Wolff, V., (2010), Poredbena analiza Haaških i Rotterdamskih pravila, Zagreb: Poredbeno pomorsko pravo, 49(164), pp. 169-210.

Skorupan Wolff, V., (2007), Odgovornost prijevoznika prema Nacrtu konvencije o prijevozu stvari (u cijelosti ili djelomično) (morem), Zagreb: Poredbeno pomorsko pravo, 46(161), pp. 145 - 189.

Thomas, R., (2010), The carriage of goods by sea under the Rotterdam Rules, London: Lloyd's List.

Ziegler, A., Schelin, J. and Zunarelli, S., (2010), The Rotterdam Rules 2008, Commentary to the United Nations Convention on Contracts for the International Carriage of Goods Wholly or Partly by Sea, The Netherlands: Kluwer Law International. 